\title{
Studies on Development and Storage Quality Evaluation of Syrup Prepared from Wild Pomegranate (Punica granatum L.) Fruits
}

\author{
N.S. Thakur, G.S. Dhaygude, Hamid", Pradeep Kumar and Abhimanyu Thakur \\ Department of Food Science and Technology, Dr YS Parmar University of Horticulture and \\ Forestry, Nauni, Solan, HP 173230, India \\ *Corresponding author
}

\begin{abstract}
A B S T R A C T
Wild pomegranate is not a cultivated fruit but found in wild form in certain pockets of six districts of Himachal Pradesh viz., Shimla, Sirmour, Solan, Mandi, Kullu and Chamba.

Keywords

Wild pomegranate,

Syrup, Storage,

Anthocyanins,

Phenols, Packaging material

Article Info

Accepted:

07 January 2018

Available Online:

10 February 2018

The present studies were conducted to develop syrup from wild pomegranate and its quality evaluation during storage. Different combinations of juice $(25,30,35$ and $40 \%)$ and TSS (65 and $70{ }^{\circ} \mathrm{B}$ ) were tried to standardize proper combination for the development of syrup. Out of 8 different treatment combinations of juice and TSS tried, syrup with 40 per cent juice, $70{ }^{\circ} \mathrm{B}$ TSS and 1.80 per cent acid was found to be best on the basis of sensory and some physico-chemical characteristics of the product. The standardized recipe $\left(\mathrm{T}_{8}\right)$ of syrup contains higher ascorbic acid content $(7.05 \pm 0.03 \mathrm{mg} / 100 \mathrm{ml})$, anthocyanins $(8.19 \pm 0.06 \mathrm{mg} / 100 \mathrm{ml})$ and higher total phenols $(45.82 \pm 0.58 \mathrm{mg} / 100 \mathrm{ml})$. The syrup prepared by following the best selected recipe was packed in glass and PET (polyethylene terephthalate) bottles and stored for six months under ambient $\left(20-25{ }^{\circ} \mathrm{C}\right)$ and refrigerated temperature $\left(4-7^{\circ} \mathrm{C}\right)$ conditions. It could safely be stored for a period of six months under both the ambient and refrigerated storage conditions without much changes in various quality characteristics. However quality of the product was retained better in glass than PET bottles under refrigerated condition as compare to ambient storage condition.
\end{abstract}

\section{Introduction}

Pomegranate is believed to be originated in South-West Asia probably in Iran and some adjoining countries. However, the wild and semi-wild pomegranates still exist in North Syria in Gilead and on Mount Carmel. Wild pomegranate (Punica granatum L.) is a shrub of family punicaceae and is one of the most important wild fruit, which resembles with cultivated pomegranate for various morphological characters (Sharma and Sharma, 1990). It is widely distributed in drier and sub-marginal land of mid-hill regions of outer Himalaya, where slightly hot climate characterized by dry summer and fairly pronounced winter prevails. The Indian Himalaya holds a good diversity of wild pomegranate. In India, pomegranate grows wild in western Himalayan region that include states like Himachal Pradesh, Uttrakhand, Jammu and Kashmir (Pandey et al., 2008) at an altitude of 900 to $1800 \mathrm{~m}$ above mean sea level. In Himachal Pradesh, it is distributed in some pockets of Solan, Sirmour, Mandi, Shimla, Kullu and Chamba districts (Bhrot, 
1998). This fruit has also got various medicinal properties due to presence of various bioactive compounds including phenolic antioxidants. The arils of wild pomegranate are rich source of organic acids besides having appreciable amount of sugars, anthocyanins, phenols, ascorbic acid etc. It also contains good amount of minerals like phosphorus, calcium, potassium and iron (Parmar and Kaushal, 1982). Citric acid is present in sufficient quantity in this fruit besides, other acids like malic, succinic and tartaric acid (Saxena et al., 1987). This fruit has also got various medicinal properties like laxative, diuretic and used for curing vomiting, sore throat, brain diseases, spleen complaints, chest troubles, scabies, bronchitis, earache, liver and kidney disorders (Kirtikar and Basu, 1985). The traditional knowledge reveals that the bark and rind of pomegranate fruits is used in tanning and as vermifuge especially in cough and cold. Extracts of all parts of the fruit appear to have therapeutic properties (Lansky and Newman, 2007). Devi et al., (2011) have reported peel extract of daru, have important antibacterial activities which was found higher against Gram-positive bacteria than Gram-negative bacteria.

Traditionally, arils of wild pomegranates are utilized for preparation of dried condiment (anardana) because fresh arils of this fruit are quite tart in taste and mostly not liked by consumers due to its extremely acidic nature (Sharma and Thakur, 2016). It is paradox that such a miracle fruit having enormous potential for therapeutic use has never been utilized commercially for value addition except in the form of anardana.

An important reason for this is being lack of awareness regarding its nutritive value, use and unavailability of technology for its processing. This technology developed will benefit the poorer sections of the rural areas as the raw material is available only in some parts of those districts in abundance. So, being a rich source of antioxidants and organic acids, present studies were under taken with the objective to develop syrup from this wild fruit and to study effect of storage conditions and packaging material on its quality characteristics.

\section{Materials and Methods}

\section{Standardization of the recipe}

Wild pomegranate fruits harvested at optimum maturity were procured from Narag area of Sirmour district of Himachal Pradesh, India and brought to the department of Food Science and Technology, Nauni, Solan, HP. Fruits after thorough washing in water were used for physico-chemical analysis and juice extraction. Fruits were cut into parts and arils were extracted manually. The extracted arils were used for extraction of juice by food processor (Maharaja make). Fruit syrup was prepared by mixing the wild pomegranate juice in sugar syrup of different concentrations as given in Table 1. Although, efforts were made to exploit the natural acid present in the juice of this fruit but to get the desirable concentration of acid (1.8\%) in the syrup some acid in the form of citric acid was added in all the combinations. Sodium benzoate (600 ppm) was added in all the treatment combinations as a preservative.

\section{Packaging and storage}

The syrup prepared by following the best selected recipe was packed in pre-sterilised glass and PET bottles (700 ml capacity). All the packed products were properly labelled and stored in ambient $\left(20-25{ }^{\circ} \mathrm{C}\right)$ and low temperature $\left(4-7{ }^{\circ} \mathrm{C}\right)$ conditions for six months. The physico-chemical and sensory characteristics of best selected product were estimated at zero, three and six months of storage. 
Physico-chemical analysis and sensory evaluation

The colour of syrup in terms of different tintometer colour units (TCU) was observed with Tintometer (Lovibond Tintometer Model-E). Moisture, total solids, TSS, reducing and total sugars, titratable acidity and anthocyanins of prepared product were determined according to method described by Ranganna (2009) and AOAC (1990). The $\mathrm{pH}$ of the samples was determined by using a digital $\mathrm{pH}$ meter (CRISON Instrument, Ltd, Spain). Total phenols content $(\mathrm{mg} / 100 \mathrm{~g}$ as tannic acid) was determined by FolinCiocalteu procedure given by Singleton and Rossi (1965). Nine points hedonic rating test was followed for conducting the sensory evaluation of syrup (Amerine et al., 1965). The panel of ten judges was selected to evaluate the product for sensory parameters such as colour, body, taste, aroma and overall acceptability.

\section{Statistical analysis}

Data on physico-chemical characteristics of wild pomegranate syrup was analysed by Completely Randomized Design (CRD) before and during storage, whereas, data pertaining to the sensory evaluation were analyzed by using Randomized Block Design (RBD) as described by Mahony (1985). The experiments on recipe standardization were replicated three times and for storage studies were replicated five times.

\section{Results and Discussion}

Standardization of recipe for the preparation of wild pomegranate syrup

The data regarding the physico-chemical and sensory characteristics of wild pomegranate syrup prepared by following different recipes are presented in the Table 2 and 3 .

\section{Physico-chemical characteristics}

The data in Table 2 highlight that visual red and yellow TCU of different recipes varied from 9.00 to 15.30 and 1.10 to 1.46 , respectively.

The highest (15.30) red TCU were noticed in recipe $T_{8}$ which was statistically at par with $T_{4}$ whereas, lowest (9.00) red TCU were record in $\mathrm{T}_{5}$. The maximum (1.46) yellow TCU were recorded in $\mathrm{T}_{5}$ which was statistically at par with $\mathrm{T}_{1}, \mathrm{~T}_{2}, \mathrm{~T}_{6}$ and $\mathrm{T}_{7}$ and minimum (1.10) in $\mathrm{T}_{3}$ and $\mathrm{T}_{4}$.

TSS of the product was kept constant at two levels, in first four recipes it was $65{ }^{\circ} \mathrm{B}$ and rest $70{ }^{0} \mathrm{~B}$. The titratable acidity of all the recipes was kept constant at 1.80 per cent.

Further, the highest $(7.05 \mathrm{mg} / 100 \mathrm{ml})$ ascorbic acid was observed in recipe $\mathrm{T}_{8}$ and lowest $(4.35 \mathrm{mg} / 100 \mathrm{ml})$ in recipe $\mathrm{T}_{1}$. The $\mathrm{pH}$ value of different recipes of wild pomegranate syrup ranged from 3.40 to 3.45 , however, there were no significant difference among the $\mathrm{pH}$ values of all the recipes.

\section{Sensory characteristics}

Table 3 reveals that the highest score as 8.50 , 8.20 and 8.30 were awarded to colour, body and taste, respectively in recipe $\mathrm{T}_{8}$, and lowest score as $6.00,6.25$ and 6.00 for the same respective characteristics in recipe $T_{1}$. Similarly highest score of aroma (8.50) and overall acceptability (8.35), were observed in $\mathrm{T}_{8}$ and lowest as 6.20 and 6.00 were observed in the respective parameters in recipe $T_{1}$.

From above results it was concluded that recipe with 40 per cent juice and $70{ }^{\circ} \mathrm{B}$ TSS $\left(\mathrm{T}_{8}\right.$ ) was found to be best on the basis of sensory and some physico-chemical characteristics of syrup, which was selected for further studies. 


\section{Physico-chemical characteristics of standardized recipe of wild pomegranate syrup}

From the results it was observed that this standardized recipe of wild pomegranate syrup (Table 4) contained relatively higher ascorbic acid content along with best sugar acid blend, which is because of higher content of fruit juice used in this recipe. This recipe also obtained maximum scores for sensory parameters like colour, body, taste, aroma and overall acceptability, which may be due to higher juice content, best combination of juice and syrup, best sugar-acid blend in the product and finally all these factors might have led the judges to award the highest scores to this recipe.

\section{Storage of wild pomegranate syrup}

\section{Physico-chemical characteristics}

\section{Colour}

The decrease in red and yellow TCU (Figure $1 \mathrm{a}$ and $1 \mathrm{~b}$ ) of syrup was observed during storage. However, decrease was significantly lower under refrigerated storage conditions than ambient conditions.

The reason for decrease in colour units of syrup during storage might be due to degradation of anthocyanins pigment. However, these pigments degraded at slower rate in low temperature hence less decrease observed in refrigerated conditions.

Less decrease in colour units of syrup packed in glass bottle observed because of slower rate of chemical reactions in product packed in glass bottle as a result of difference in their thermal conductance properties. Similar trend of decrease in red and yellow colour units were observed by Thakur and Thakur (2017) in box myrtle syrup.
TSS

The TSS of syrup increased non-significantly during storage (Figure 1c) and this increase in TSS during storage might be due to hydrolysis of polysaccharides into monosaccharide and soluble disaccharides (Gould, 1983). Our results are in conformity with the findings of Reddy and Chikkasubbanna (2009) in aonla syrup.

\section{Sugars}

Reducing and total sugars of syrup (Figure 1d and 1e) showed a significant increase during storage which was comparatively less in refrigerated storage conditions than in ambient conditions. This increase might be due to hydrolysis of starch into sugars as well as conversion of complex polysaccharides into simple sugars and conversion of non-reducing to reducing sugars. As far as packaging material is concerned, more increase in sugars was recorded in syrup packed in PET bottle as compared to glass bottle. This might be due to the faster rate of chemical reactions in the product packed in PET bottle because of faster heat absorption of PET packaging material than glass. Similar results have been observed by Choudhary et al., (2012) in aonla syrup and Hamid et al., (2017) in mulberry syrup.

\section{Titratable acidity}

A non-significant decrease in titratable acidity of syrup was observed during storage, (Figure 1f) which might be due to co-polymerization of organic acids with sugars and amino acids. Similar results were recorded by Reddy and Chikkasubbanna (2009) in aonla syrup.

\section{Ascorbic acid}

Ascorbic acid content of syrup decreased significantly during storage, however, the decrease was lower in refrigerated storage 
conditions than ambient conditions (Table 5). Decrease in ascorbic acid content might be due to its degradation into dehydro-ascorbic acid or furfural during storage.

Less decrease of ascorbic acid in refrigerated storage might be due to the slower rate of its degradation in low temperature as compared to ambient storage conditions because of its susceptibility to high temperature. Retention of higher ascorbic acid in glass bottle may be due to the slower rate of reactions in glass bottle as it absorbs heat at slower rate as compared to PET bottle during storage. Our findings are in agreement with the results reported by Thakur et al., (2013) in wild pomegranate syrup (with arils) and Khurdiya and Roy (1984) in jamun syrup.

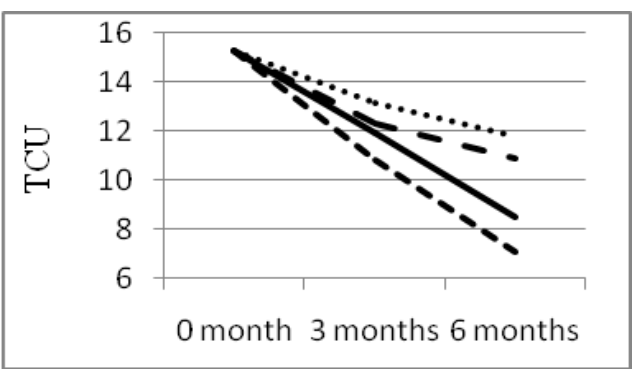

a. Red TCU

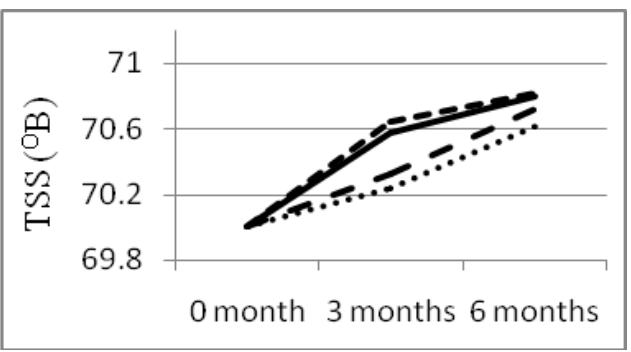

c. TSS $\left({ }^{\circ} \mathrm{B}\right)$

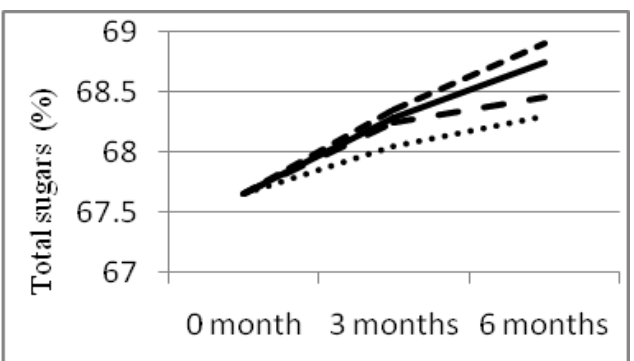

e. Total sugars (\%)

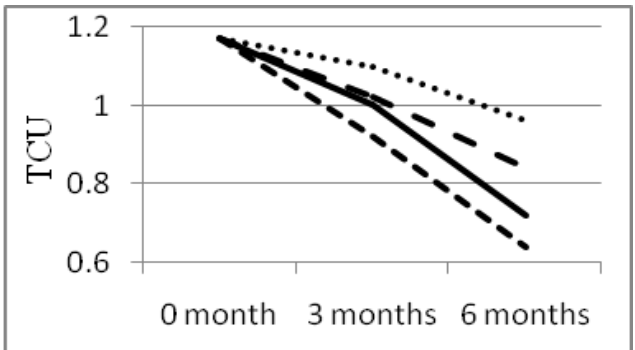

b. Yellow TCU

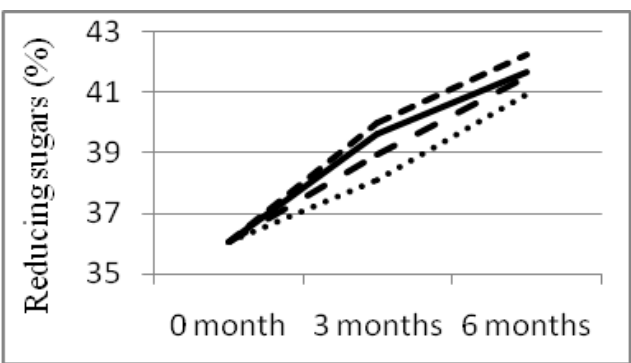

d. Reducing sugars (\%)

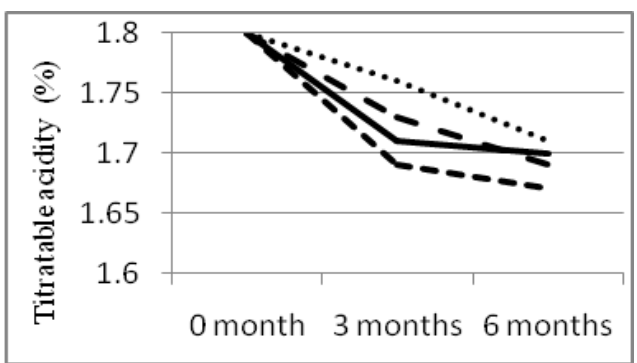

f. Titratable acidity (\%)

Ambient glass

- - Ambient PET

Refrigerated glass

- - Refrigerated PET

Figure 1: Effect of storage on physico-chemical characteristics of wild pomegranate syrup 


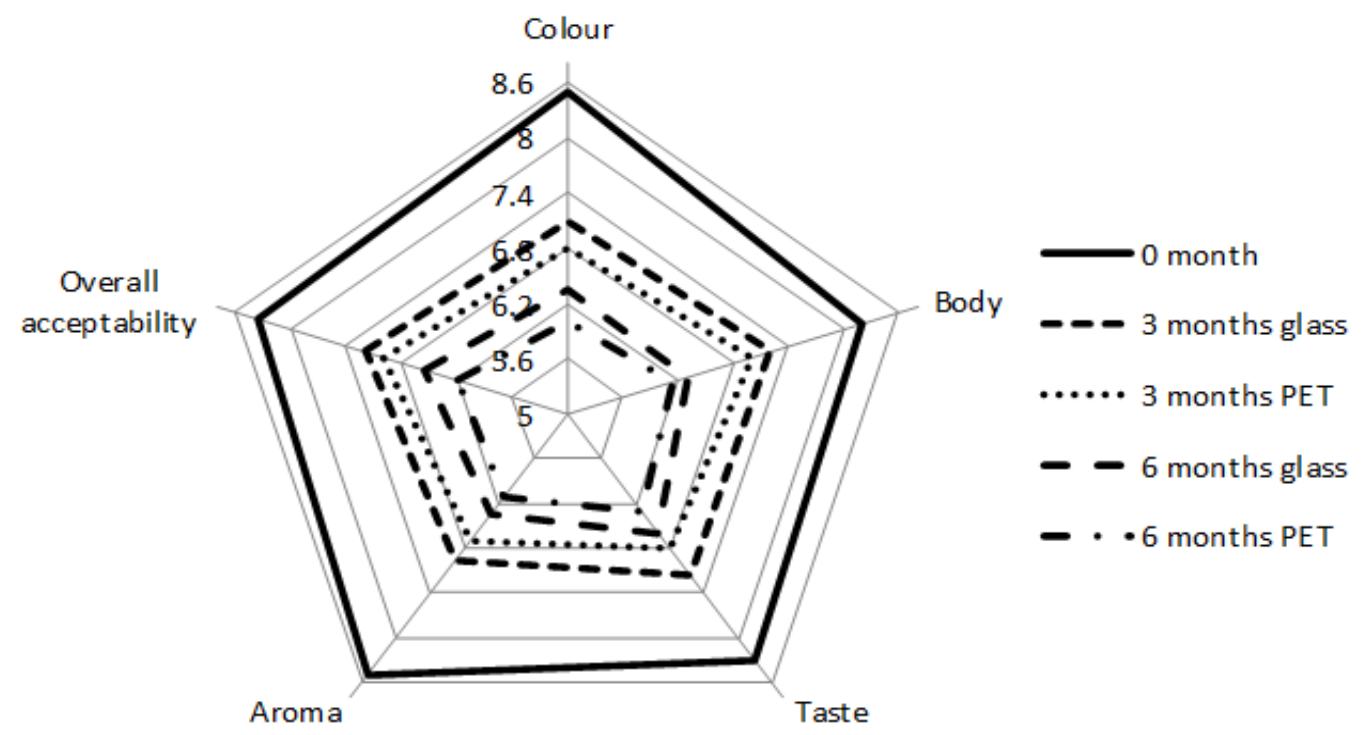

Figure 2: Effect of storage and packaging on sensory characteristics of wild pomegranate syrup stored under ambient conditions
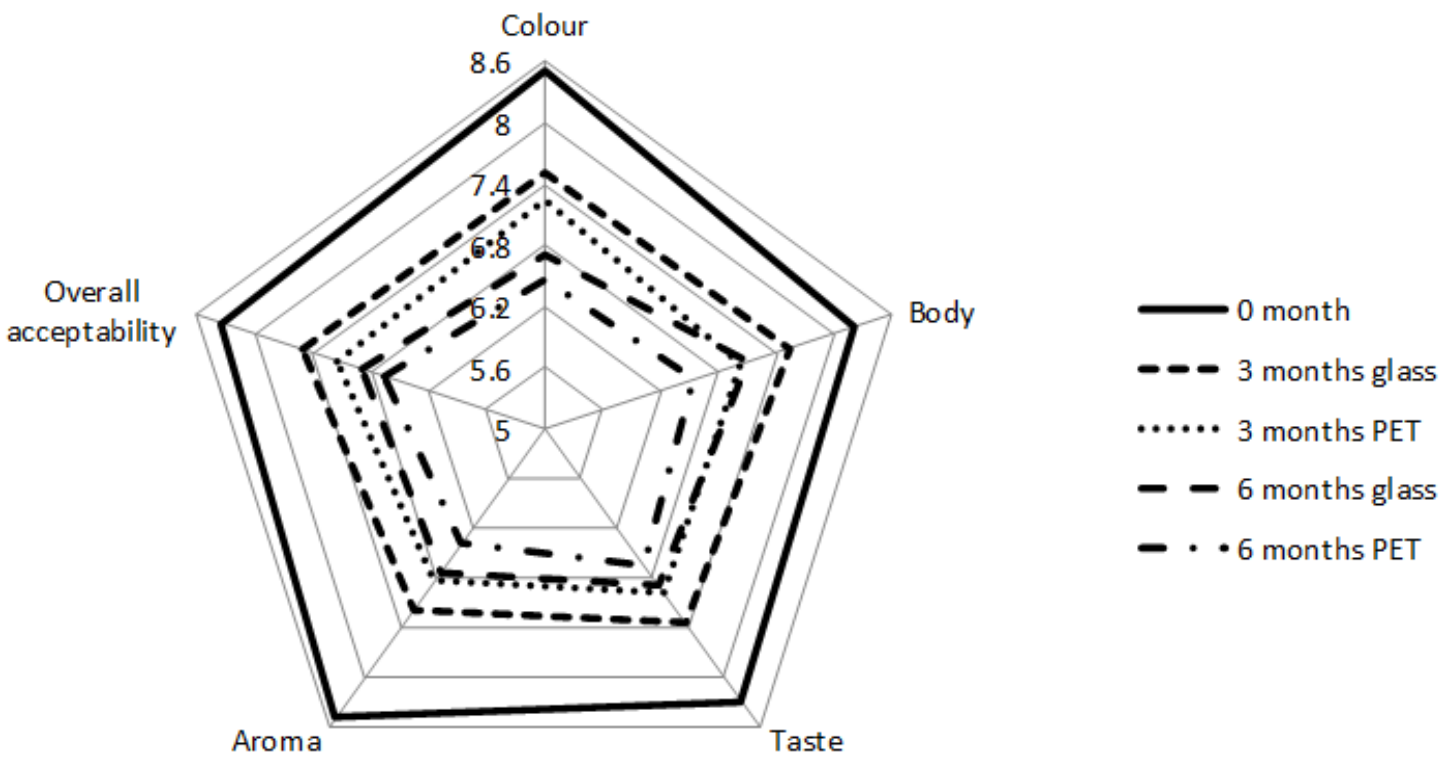

Figure 3: Effect of storage and packaging on sens ory characteristics of wild pomegranate syrup stored under refrigerated conditions 
Table.1 Treatment details of syrup

\begin{tabular}{|l|l|l|l|l|l|l|l|l|}
\hline Treatments (T) & $\mathrm{T}_{1}$ & $\mathrm{~T}_{2}$ & $\mathrm{~T}_{3}$ & $\mathrm{~T}_{4}$ & $\mathrm{~T}_{5}$ & $\mathrm{~T}_{6}$ & $\mathrm{~T}_{7}$ & $\mathrm{~T}_{8}$ \\
\hline Juice $(\%)$ & 25 & 30 & 35 & 40 & 25 & 30 & 35 & 40 \\
\hline TSS $\left({ }^{0} \mathbf{B}\right)$ & 65 & 65 & 65 & 65 & 70 & 70 & 70 & 70 \\
\hline
\end{tabular}

Table.2 Physico-chemical characteristics of different recipes of Wild pomegranate syrup

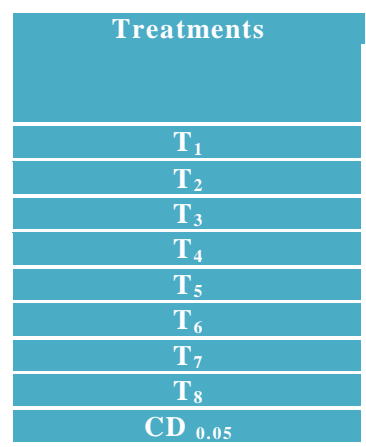

\begin{tabular}{|c|c|}
\hline \multicolumn{2}{|c|}{ Colour } \\
\hline R & TCU) \\
\hline 9.05 & 1.40 \\
\hline 11.32 & 1.30 \\
\hline 13.18 & 1.10 \\
\hline 15.04 & 1.10 \\
\hline 9.00 & 1.46 \\
\hline 11.35 & 1.35 \\
\hline 13.28 & 1.28 \\
\hline 15.30 & 1.17 \\
\hline 0.42 & 0.20 \\
\hline
\end{tabular}

Physico-chemical characteristics

Table.3 Sensory characteristics (score) of different recipes of wild pomegranate syrup

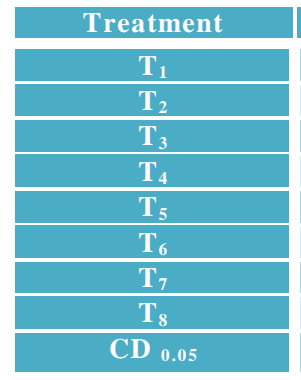

\begin{tabular}{|c|c|}
\hline Colour & Body \\
\hline 6.00 & 6.25 \\
\hline 6.45 & 6.75 \\
\hline 6.85 & 6.95 \\
\hline 8.25 & 7.80 \\
\hline 6.15 & 6.50 \\
\hline 6.80 & 6.90 \\
\hline 7.00 & 7.20 \\
\hline 8.50 & 8.20 \\
\hline 0.27 & 0.31 \\
\hline
\end{tabular}

\begin{tabular}{|c|c|c|}
\hline Taste & Aroma & Overall acceptability \\
\hline 6.00 & 6.20 & 6.00 \\
\hline 6.70 & 7.10 & 6.65 \\
\hline 7.00 & 7.10 & 6.90 \\
\hline 7.40 & 7.95 & 7.80 \\
\hline 6.20 & 6.25 & 6.05 \\
\hline 6.85 & 7.10 & 6.80 \\
\hline 7.15 & 7.35 & 7.25 \\
\hline 8.30 & 8.50 & 8.35 \\
\hline 0.62 & 0.51 & 0.30 \\
\hline
\end{tabular}

Table.4 Physicochemical characteristics of standardized recipe of Wild pomegranate syrup

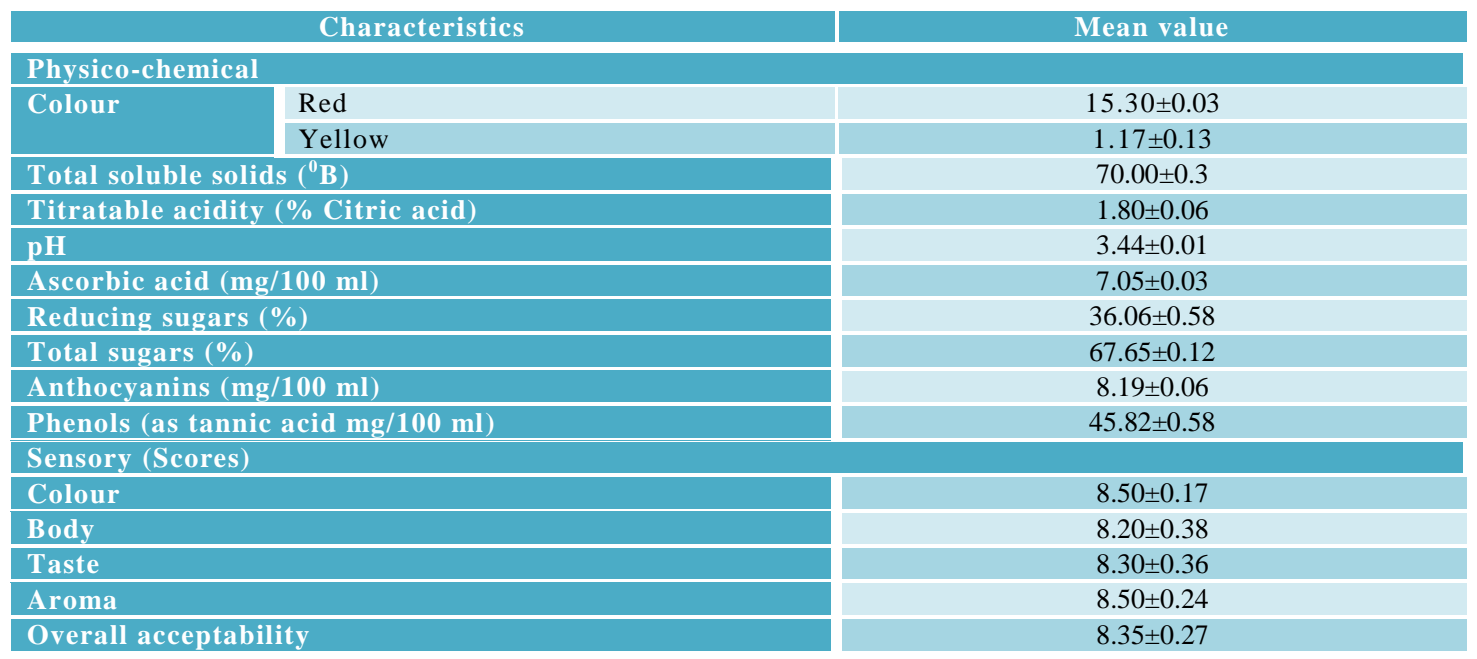


Table.5 Effect of packaging and storage on ascorbic acid $(\mathrm{mg} / 100 \mathrm{ml})$ of Wild pomegranate syrup

\begin{tabular}{|c|c|c|c|c|c|c|c|c|}
\hline $\mathbf{V}$ & \multicolumn{3}{|c|}{$\begin{array}{c}\text { Ambient storage } \\
\text { (Months) }\end{array}$} & Mean & \multicolumn{3}{|c|}{$\begin{array}{l}\text { Refrigerated storage } \\
\text { (Months) }\end{array}$} & \multirow[t]{2}{*}{ Mean } \\
\hline S & $\mathbf{0}$ & 3 & 6 & & $\mathbf{0}$ & 3 & 6 & \\
\hline $\mathrm{T}_{1}$ & 7.05 & 4.05 & 2.80 & 4.63 & 7.05 & 4.80 & 3.71 & 5.19 \\
\hline $\mathbf{T}_{2}$ & 7.05 & 3.75 & 2.50 & 4.43 & 7.05 & 4.30 & 3.42 & 4.92 \\
\hline Mean & 7.05 & 3.90 & 2.65 & 4.53 & 7.05 & 4.55 & 3.57 & 5.06 \\
\hline \multicolumn{5}{|c|}{ TxS interaction Table } & \multicolumn{4}{|l|}{$\mathrm{CD}_{0.05}$} \\
\hline Treatment & 0 & 3 & 6 & Mean & $\mathrm{T}=0.14$ & $\mathrm{~T} \times \mathrm{S}=\mathrm{NS}$ & \multicolumn{2}{|c|}{$\mathrm{T}=$ packaging material } \\
\hline $\mathrm{T}_{1}$ & 7.05 & 4.43 & 3.26 & 4.91 & $S=0.17$ & $\mathrm{~T} \times \mathrm{V}=\mathrm{NS}$ & \multicolumn{2}{|c|}{$\mathrm{S}=$ Storage period } \\
\hline $\mathbf{T}_{2}$ & 7.05 & 4.03 & 2.96 & 4.68 & $V=0.14$ & $\mathrm{~S} \times \mathrm{V}=0.24$ & \multicolumn{2}{|c|}{$\mathrm{V}=$ Storage conditions } \\
\hline Mean & 7.05 & 4.23 & 3.11 & & & $\mathrm{~T} \times \mathrm{S} \times \mathrm{V}=\mathrm{NS}$ & \multicolumn{2}{|c|}{$\mathrm{T}_{1}=$ Glass bottle } \\
\hline & & & & & & & \multicolumn{2}{|c|}{$\mathrm{T}_{2}=$ PET bottle } \\
\hline
\end{tabular}

Table.6 Effect of packaging and storage on anthocyanins $(\mathrm{mg} / 100 \mathrm{ml})$ of Wild pomegranate syrup

\begin{tabular}{|c|c|c|c|c|c|c|c|c|}
\hline \multirow[t]{2}{*}{$\mathbf{V}$} & \multicolumn{3}{|c|}{$\begin{array}{c}\text { Ambient storage } \\
\text { (Months) }\end{array}$} & \multirow[t]{2}{*}{ Mean } & \multicolumn{3}{|c|}{$\begin{array}{c}\text { Refrigerated storage } \\
\text { (Months) }\end{array}$} & \multirow[t]{2}{*}{ Mean } \\
\hline & $\mathbf{0}$ & 3 & 6 & & $\mathbf{0}$ & 3 & 6 & \\
\hline $\mathbf{T}_{1}$ & 8.19 & 4.35 & 3.43 & 5.33 & 8.19 & 5.28 & 4.20 & 5.89 \\
\hline $\mathbf{T}_{2}$ & 8.19 & 4.07 & 2.76 & 5.01 & 8.19 & 4.86 & 3.80 & 5.62 \\
\hline Mean & 8.19 & 4.21 & 3.10 & 5.17 & 8.19 & 5.07 & 4.00 & 5.76 \\
\hline \multicolumn{5}{|c|}{ TxS interaction Table } & \multicolumn{4}{|l|}{$\mathrm{CD}_{0.05}$} \\
\hline Treatment & 0 & 3 & 6 & Mean & $\Gamma=0.06$ & $T \times S=0.12$ & \multicolumn{2}{|c|}{$\Gamma=$ packaging material } \\
\hline $\mathbf{T}_{1}$ & 8.19 & 4.82 & 3.82 & 5.61 & $\mathrm{~S}=0.08$ & $\Gamma \times V=N S$ & \multicolumn{2}{|c|}{$\mathrm{S}=$ Storage period } \\
\hline $\mathbf{T}_{2}$ & 8.19 & 4.47 & 3.28 & 5.31 & $V=0.06$ & $\mathrm{~S} \times \mathrm{V}=0.12$ & \multicolumn{2}{|c|}{$V=$ Storage conditions } \\
\hline Mean & 8.19 & 4.64 & 3.55 & & & $\Gamma \times \mathrm{S} \times \mathrm{V}=\mathrm{NS}$ & \multicolumn{2}{|c|}{$\Gamma_{1}=$ Glass bottle } \\
\hline & & & & & & & \multicolumn{2}{|c|}{$\Gamma_{2}=$ PET bottle } \\
\hline
\end{tabular}

Table.7 Effect of packaging and storage on phenols (as tannic acid mg/100 ml) of Wild pomegranate syrup

\begin{tabular}{|c|c|c|c|c|c|c|c|c|}
\hline $\mathbf{V}$ & \multicolumn{3}{|c|}{$\begin{array}{c}\text { Ambient storage } \\
\text { (Months) }\end{array}$} & Mean & \multicolumn{3}{|c|}{$\begin{array}{c}\text { Refrigerated storage } \\
\text { (Months) }\end{array}$} & \multirow[t]{2}{*}{ Mean } \\
\hline $\mathbf{S}$ & $\mathbf{0}$ & 3 & 6 & & $\mathbf{0}$ & 3 & 6 & \\
\hline $\mathbf{T}_{1}$ & 45.82 & 41.91 & 38.88 & 42.20 & 45.82 & 43.89 & 40.79 & 43.50 \\
\hline $\mathbf{T}_{2}$ & 45.82 & 40.16 & 37.30 & 41.09 & 45.82 & 41.96 & 39.25 & 42.34 \\
\hline Mean & 45.82 & 41.03 & 38.09 & 41.65 & 45.82 & 42.92 & 40.02 & 42.92 \\
\hline \multicolumn{5}{|c|}{ TxS interaction Table } & \multicolumn{4}{|l|}{$\mathrm{CD}_{0.05}$} \\
\hline Treatment & 0 & 3 & 6 & Mean & $\mathrm{T}=0.31$ & $\mathrm{~T} \times \mathrm{S}=0.54$ & \multicolumn{2}{|c|}{$\mathrm{T}=$ packaging material } \\
\hline $\mathbf{T}_{1}$ & 45.82 & 42.90 & 39.83 & 42.85 & $S=0.38$ & $\mathrm{~T} \times \mathrm{V}=\mathrm{NS}$ & \multicolumn{2}{|c|}{$\mathrm{S}=$ Storage period } \\
\hline $\mathrm{T}_{2}$ & 45.82 & 41.06 & 38.28 & 41.72 & $\mathrm{~V}=0.31$ & $\mathrm{~S} \times \mathrm{V}=0.54$ & \multicolumn{2}{|c|}{$\mathrm{V}=$ Storage conditions } \\
\hline Mean & 45.82 & 41.92 & 39.05 & & & $\mathrm{~T} \times \mathrm{S} \times \mathrm{V}=\mathrm{NS}$ & \multicolumn{2}{|c|}{$\mathrm{T}_{1}=$ Glass bottle } \\
\hline & & & & & & & \multicolumn{2}{|c|}{$\mathrm{T}_{2}=$ PET bottle } \\
\hline
\end{tabular}


Table. 8 Cost of production of wild pomegranate syrup (for 1 liter)

\begin{tabular}{|c|c|c|c|c|}
\hline \multirow{2}{*}{ Particulars } & \multirow[t]{2}{*}{ Quantity } & \multirow[t]{2}{*}{ Rate (Rs) } & \multicolumn{2}{|c|}{ Amount (Rs) } \\
\hline & & & $\mathbf{T}_{1}$ (Glass bottle) & $\mathrm{T}_{2}$ (PET bottle) \\
\hline Wild pomegranate & $1010.00 \mathrm{~g}$ & $50 / \mathrm{kg}$ & 50.50 & 50.50 \\
\hline Sugar & $640.00 \mathrm{~g}$ & $40 / \mathrm{kg}$ & 25.60 & 25.60 \\
\hline Citric acid & $2.64 \mathrm{~g}$ & $450 / \mathrm{kg}$ & 1.19 & 1.19 \\
\hline Sodium benzoate@600ppm & $0.60 \mathrm{~g}$ & $480 / \mathrm{kg}$ & 0.29 & 0.29 \\
\hline \multicolumn{5}{|l|}{ Packaging cost } \\
\hline Glass bottle $(700 \mathrm{ml})$ & 1 & 5/bottle & 5.00 & - \\
\hline PET bottle $(700 \mathrm{ml})$ & 1 & 6/bottle & - & 6.00 \\
\hline Processing cost @10\% & - & - & 8.26 & 8.36 \\
\hline Total cost & - & - & 90.84 & 91.94 \\
\hline Profit @20\% & - & - & 18.17 & 18.39 \\
\hline Sale price & - & - & 109.01 & 110.33 \\
\hline Sale price for $700 \mathrm{ml}$ bottle & - & - & 76.31 & 77.23 \\
\hline
\end{tabular}

\section{Anthocyanins}

A significant decrease in anthocyanins content of syrup was recorded during the storage (Table 6) and more retention of anthocyanins was observed under refrigerated storage conditions than ambient conditions. Loss of anthocyanins in syrup might be due to their high susceptibility to auto oxidative degradation during storage. More retention of this characteristic in the product in refrigerated conditions as compared to ambient might be due to slower rate of auto oxidation of anthocyanins in refrigerated conditions. Less decrease of anthocyanins in glass bottle may be due to the slower rate of their chemical reactions in glass bottle as a result of difference in their thermal conductance properties during storage. Similar findings were recorded by Kannan and Thirumaran (2002) in jamun beverage and Hamid et al., (2017) in mulberry syrup.

\section{Total phenols}

A significant decrease in phenols content of syrup was recorded during storage (Table 7) and this decrease was lower under refrigerated storage conditions than ambient conditions. The decrease in phenols content in syrup during storage might be due to their involvement in the formation of polymeric compounds by complexing with protein and their subsequent precipitations as observed by Abers and Wrolstad (1979).

These reactions may be slower in refrigerated storage conditions and faster in ambient conditions during storage. As far as packaging material is concerned, more retention of phenols in syrup packed in glass bottle than PET bottle might be due to the difference in their thermal conductance properties which affect internal decomposition reactions. Similar trend of decrease in phenols content have been reported by Thakur and Thakur (2017) in box myrtle syrup and Hamid et al., (2017) in mulberry syrup.

\section{Sensory characteristics of wild pomegranate syrup during storage}

The decrease in colour, body, taste, aroma and overall acceptability scores of syrup was observed during storage. However, decrease in sensory score was less in refrigerated storage conditions (Fig. 2) than ambient (Fig. 3). The colour scores of syrup decreased significantly during storage which might be due to degradation of colour pigment (anthocyanins) 
and browning caused by copolymerization of organic acids of the product (Hamid et al., 2017). As far as packaging material is concerned, there was significant effect of packaging materials on the colour scores of syrup. While, the possible reason for decrease in body scores was the formation of precipitates in the product as a result of interactions between phenols and protein as well as the formation of cation complexes with pectin and phenols during storage. The formation of precipitates in the product might have led the judges to award the lower scores. Decrease of low body scores in refrigerated storage conditions might be due to the formation/ appearance of precipitates in lower amount as a result of slower reaction rate in low temperature. However, taste scores of syrup decreased with advancement of storage and the decrease was found less in refrigerated conditions as compared to ambient conditions. The taste scores of syrup packed in glass bottle were retained higher as compared to PET bottle. The decrease in taste scores of product during storage might be due to loss of sugar-acid blend responsible for taste (Thakur and Thakur, 2017). Retention of higher taste scores in refrigerated conditions might be due to the better retention of original sugar-acid-salt blend as a result of slow reaction rate contributing change in this blend. However, the retention of better taste scores of syrup in glass bottle might be due to the better retention of sugar acidblend as a result of slower reaction rate in glass bottle as compared to PET because glass absorb heat at slower rate than PET. Similar observations of decrease in taste scores of the product during storage were also noticed by Hamid et al., (2017) in mulberry syrup. The loss of aroma scores during storage might be due to the possible loss of volatile aromatic compounds which led the judges to award the lower scores. Decrease in overall acceptability scores might be due to the loss in appearance, flavour compounds and uniformity of the product during storage. Syrup packed in glass bottles retained more sensory scores than PET bottles. The retention of better overall sensory scores of syrup in glass bottles might be due to the better retention of above given factors as a result of slower reaction rate in glass bottles as compared to PET. The similar results have also been reported earlier by Choudhary et al., (2012) in aonla syrup, Thakur and Thakur (2017) in box myrtle syrup and Hamid et al., (2017) in mulberry syrup.

Out of 8 different treatment combinations syrup recipe $\left(\mathrm{T}_{8}\right)$ containing 40 per cent juice, $70{ }^{\circ} \mathrm{B}$ TSS and 1.80 per cent acid was found to be best on the basis of its physico-chemical characteristics and sensory parameters, which could be stored safely for a period of six months under both storage conditions and also in both packaging materials like PET and glass bottles. The best quality of this beverage could be maintained in glass bottle stored under refrigerated storage conditions as compared to PET bottle. The cost of the syrup prepared from wild pomegranates was comparable to the cost of the similar products in the market (Table 8). The results make it clear that wild pomegranate fruit can be successfully utilized for the preparation of different value added products.

\section{References}

Abers, J.E., and Wrolstad, R.E. 1979. Causative factors of colour determination in strawberry preserves during processing and storage. Journal of Food Science, 44(1): 75-81.

Amerine, M.A., Pangborn, R.M., and Roessler, E.B. 1965. Principles of sensory evaluation of food. Academic Press: London. pp. 236-268.

AOAC. 1990. Official methods of analysis of the association of official analytical chemists. Association of Official Analytical Chemists, Washington, DC, USA.

Bhrot, N.P. 1998. Genetical analysis of wild pomegranate (Punica granatum L.) for same growth ecological and quality characters. Ph. D. Thesis. Dr Y S Parmar University of Horticulture and Forestry, Nauni, Solan (H P), 156p.

Choudhary, M.L., Verma, I.M., Singh, J., and Godara, S.L. 2012. Studies on 
biochemical changes in aonla (Emblica officinalis Gaertn.) syrup under storage condition. The Horticulture Journal, 25(1\&2): 7-11.

Devi, A., Singh, V., and Bhatt, A.B. 2011. Comparative antibacterial study of different extract of pomegranate and its wild variety. International Journal of Pharmaceutical Sciences and Research, 2(10): 2647-2650.

Gould, W.A. 1983. Tomato production, processing and quality evaluation. 2nd ed. Avi Publishing Company, West port, CJ.

Hamid, Thakur, N.S., Kumar, P., and Thakur, A. 2017. Development of Syrup from Mulberry (Morus alba L.) and its Quality Evaluation under Ambient and Refrigerated Storage Conditions. International Journal of Bio-resource and Stress Management, 8(1): 116-121.

Kannan, S., and Thirumaran, A.S. 2002. Studies on storage behaviour of jamun products. Beverage and Food World, 29(3): 32-33.

Khurdiya, D.S., and Roy, S.K. 1984. Studies on stability of anthocyanins during storage. Indian Food Packer, 28(10): 5-8.

Kirtikar, K.R., and Basu, B.D. 1985. Indian Medicinal Plants. Lalit Mohan Basu Publishers, Dehradun. 1084p.

Lansky, E.P., and Newman, R.A. 2007. Punica granatum (pomegranate) and its potential for prevention and treatment of inflammation and cancer. $J$ Ethnopharmacol, 19(2): 177- 206.

Mahony, M.O. 1985. Sensory evaluation of food: statistical methods and procedures. Marcel Dekker, New York, pp 168-169.

Pandey, A., Tomer, A.K., Bhandari, D.C., and Pareek, S.K. 2008. Towards collection of Wild relatives of crop plants in India. Genet. Resour. Crop Evol., 55: 187-202. Parmar, C., and Kaushal, M.K. 1982. Wild Fruit of Sub-himalayan Region. Kalyani Publisher, New Delhi. 148p.

Ranganna, S. 2009. Handbook of analysis and quality control for fruit and vegetable products. Tata McGraw-Hill, New Delhi, India. pp1112.

Reddy, A.H., and Chikkasubbanna, V. 2009. Studies on the storage behaviour of amla syrup. The Asian Journal of Horticulture, 4(1): 5-9.

Saxena, A.K., Manan, J.K., and Berry, S.K. 1987. Pomegranate: post-harvest technology, chemistry and processing. Indian Food Packer, 41: 43-60.

Sharma, A., and Thakur, N. S. 2016. Influence of active packaging on quality attributes of dried wild pomegranate (Punica granatum L.) arils during storage. Journal of Applied and Natural Science, 8(1): 398-404.

Sharma, S.D., and Sharma, V.K. 1990. Variation of chemical characters in some promising strains of wild pomegranate (Punica granatum L.). Euphytica 49: 131133.

Singelton, V.L., and Rossi, J.A. 1965. Colorimetry of total phenolics with phosphomolybdic-phosphotungstic acid reagents. American Journal of Enology and Viticulture 16: 144-158.

Thakur, A., and Thakur, N.S. 2017. Development of Syrup from Box Myrtle (Myrica nagi) and Its Quality Evaluation During Storage. International Journal of Agriculture Sciences, 9(8): 3862-3865.

Thakur, N.S., Dhaygude, G.S. and Joshi, V.K., 2013. Development of wild pomegranate aril-in-syrup and its quality evaluation during storage. International Journal of Food Fermentation Technology, 3(1): 3340.

\section{How to cite this article:}

Thakur, N.S., G.S. Dhaygude, Hamid, Pradeep Kumar and Abhimanyu Thakur. 2018. Studies on Development and Storage Quality Evaluation of Syrup Prepared from Wild Pomegranate (Punica granatum L.) Fruits. Int.J.Curr.Microbiol.App.Sci. 7(02): 538-548. doi: https://doi.org/10.20546/ijcmas.2018.702.068 